\title{
PENINGKATAN UNSUR HARA FOSPOR TANAH ULTISOL MELALUI PEMBERIAN PUPUK KANDANG, KOMPOS DAN PELET
}

\author{
Improvments Phosphorus Nutrient on Ultisols through Giving of Manure, \\ Composes and Pelets \\ ${ }^{1 *}$ Yafet Hendri Pasang, ${ }^{1}$ Muh. Jayadi, ${ }^{1}$ Rismaneswati \\ ${ }^{1}$ Departemen Ilmu Tanah, Fakultas Pertanian, Universitas Hasanuddin, Makassar \\ *Corresponding email: yafethendri9@gmail.com
}

\begin{abstract}
Ultisol soil has high potential for the development of dryland agriculture. However, this soil use faces obstacles because the nutrient content in Ultisol soils is generally low. This study aims to determine the effect of manure and straw compost on increasing nutrient content of phosphorus in ultisol soil. This study used a completely randomized design (CRD) with 9 levels of treatment, namely $\mathrm{P} 0=$ control, $\mathrm{P} 1$ $=$ manure 10 tons $/$ ha, $\mathrm{P} 2=$ manure 5 tons $/$ ha, $\mathrm{P} 3=$ compost 5 tons $/$ ha, $\mathrm{P} 4=$ compost 10 ton $/$ ha, P5 $=$ manure 5 tons $/$ ha + compost 10 tons / ha, $\mathrm{P} 6=$ manure 10 tons $/$ ha + compost 5 tons $/$ ha, $\mathrm{P} 7=$ pellet compost 5 tons / ha, $\mathrm{P} 8=$ compost pellets of 10 tons / ha. The treatment was repeated 3 times. The results showed that giving 10 tons / ha of manure plus 5 tons / ha of compost had a significant effect on reducing Al-dd content, and increasing $\mathrm{P}$-available, $\mathrm{pH}$, base saturation, cation exchange capacity and $\mathrm{C}$ organicon Ultisol soil. Giving pellet fertilizer 10 tons / ha gives a real influence on the growth of maize plants.
\end{abstract}

Keywords: ultisols, Phosphor, maize.

\section{PENDAHULUAN}

Di Sulawesi Selatan tanah ultisol banyak terdapat di Kabupaten Tana Toraja. Tanah ini dapat berkembang dari berbagai bahan induk, dari yang bersifat masam hingga basa. Namun sebagian besar bahan induk tanah ini adalah batuan sedimen masam. Ciri morfologi yang penting pada Ultisol adalah adanya peningkatan fraksi liat dalam jumlah tertentu pada horizon seperti yang disyaratkan dalam SoilTaxonomy (Soil Survey Staff 2003).

Ditinjau dari luasnya, tanah Ultisol mempunyai potensi yang tinggi untuk pengembangan pertanian lahan kering. Namun demikian, pemanfaatan tanah ini menghadapi kendala karakteristik tanah yang dapat menghambat pertumbuhan tanaman terutama tanaman pangan bila tidak dikelola dengan baik. Beberapa kendala yang umum pada tanah Ultisol adalah kemasaman tanah tinggi, $\mathrm{pH}$ rata-rata $<4,50$, kejenuhan Al tinggi, miskin kandungan hara makro terutama $\mathrm{P}, \mathrm{K}, \mathrm{Ca}$, dan $\mathrm{Mg}$, dan kandungan bahan organik rendah. Untuk mengatasi kendala tersebut dapat diterapkan teknologi pengapuran, pemupukan $\mathrm{P}$ dan $\mathrm{K}$, dan pemberian bahan organik.

Pupuk organik memiliki fungsi kimia dalam tanah seperti: (1) penyediaan hara makro dan mikro meskipun jumlahnya sedikit (2) meningkatkan kapasitas tukar kation (KTK) tanah; dan (3) membentuk senyawa kompleks dengan ion logam beracun ( $\mathrm{Al}, \mathrm{Fe}, \mathrm{Mn})$. Di antara jenis-jenis bahan organik, pupuk kandang merupakan pupuk organik yang terbaik, karena mengamdung unsur hara cukup lengkap, seperti N,P,K, dan unsur hara esensial lain dalam jumlah yang relatif kecil. Pupuk kandang adalah pupuk yang berasal dari ekskreta padat dan kotoran hewan, urine, dan sisa-sisa tanaman (pakan ternak) yang membusuk dengan bantuan organisme mikro tanah. Sifat pupuk kandang berbeda-beda 
tergantung jenis, umur, kesehatan dan produksi ternak, serta tingkat kematangannya.

Berdasarkan uraian di atas maka dilakukan penelitian dengan tujuan untuk mengetahui pengaruh pupuk kandang dan kompos jerami terhadap peningkatan kandungan hara fosfor pada tanah ultisol.

Kegunaan dari penelitian ini adalah sebagai bahan informasi atau referensi untuk petani ataupun peneliti yang akan melakukan penelitian mengenai penambahan pupuk kandang pada tanah ultisol di Tana Toraja.

\section{METODE PENELITIAN}

\section{Lokasi dan waktu}

Penelitian ini dilaksanakan di Experimental Farm Universitas Hasanuddin sedangkan analisis awal sampel tanah pada Laboratorium Kimia dan Kesuburan Tanah, Departemen Ilmu Tanah, Fakultas Pertanian, Universitas Hasanuddin, Makassar. Penelitian ini dilaksanakan pada bulan September 2017 hingga Oktober 2018. Lokasi pengambilan sampel tanah ultisol berada di Kelurahan Rembon, Kecamatan Rembon, Kabupaten Tana Toraja pada titik koordinat sebagai berikut $\mathrm{S} 3^{\circ} 4^{\prime} 47^{\prime \prime}, \mathrm{E}$ $119^{\circ} 47^{\prime} 16^{\prime \prime}$.

\section{Alat dan Bahan}

Alat yang digunakan dalam penelitian ini adalah pot $5 \mathrm{~kg}$, timbangan analitik, shaker, labu ukur, tabung reaksi, pipet ukur, pipet isi. Bahan yang digunakan dalam penelitian ini adalah sampel tanah ultisol, benih jagung Bisi II, air, pupuk kandang ayam,pupuk kompos jerami, dan pupuk kompos pelet.

\section{Metode Penelitian}

Penelitian ini menggunakan tanah ultisol asal Tana Toraja. Pada penelitian ini terdapat 9 perlakuan yang disusun dalam rancangan acak lengkap. Setiap perlakuan diulang sebanyak 3 kali. Berikut merupakan perlakuan yang dicobakan pada tanaman jagung:
1. Kontrol (P0)

2. Pupuk kandang (10 ton/ha) (P1)

3. Pupuk kandang (5 ton/ha) (P2)

4. Pupuk kompos (5 ton/ha) (P3)

5. Pupuk kompos (10 ton/ha) (P4)

6. Pupuk kandang (5 ton/ha) + pupuk kompos (10 ton/ha) (P5)

7. Pupuk kandang (10 ton/ha) + pupuk kompos (5 ton/ha) (P6)

8. Pupuk kompos pelet (5 ton/ha) (P7)

9. Pupuk kompos pelet (10 ton/ha) (P8)

\section{Pelaksanaan Penelitian Penyiapan Media Tanam}

Sampel tanah diambil secara komposit pada kedalaman 0 sampai $20 \mathrm{~cm}$, dikering udarakan, selanjutnya dihaluskan lalu diayak dengan ayakan bermata saring $2 \mathrm{~mm}$ untuk media tanam dan $0,5 \mathrm{~mm}$ untuk keperluan analisis awal sampel tanah. Selanjutnya sampel tanah berdiameter $2 \mathrm{~mm}$ dimasukkan ke dalam pot dengan berat $5 \mathrm{~kg} /$ pot dan diberi label.

\section{Pemupukan}

Pemberian pupuk sesuai dengan perlakuan masing-masing. Dengan dosis pupuk kandang: 5 ton/ha dan 10 ton/ha, pupuk kompos jerami: 50 ton/ha dan 10 ton/ha, pupuk kompos pelet: 5 ton/ha dan 10 ton/ha. Pemberian pupuk dilakukan 1 minggu sebelum penanaman dilakukan.

\section{Parameter Pengamatan}

Parameter yang diamati pada penelitian ini antara lain: alumunium dapat dipertukarkan, kejenuhan basa, kapasitas tukar kation, $\mathrm{P}$ tersedia, C-organik, $\mathrm{pH}$ tanah, berat segar, berat kering, tinggi tanaman, dan jumlah daun. Pengamatan dan panen dilakukan hingga umur tanaman 56 HST

\section{Analisis Data}

Data hasil pengamatan dianalisis menggunakan analisis sidik ragam (ANOVA), apabila terdapat pengaruh perlakuan yang nyata. 


\section{HASIL DAN PEMBAHASAN}

\section{Hasil}

\section{Analisis Sebelum Perlakuan}

Berikut merupakan hasil analisis tanah sebelum diberikan perlakuan untuk seluruh parameter yang digunakan pada penelitian, yaitu:

Tabel 1. Hasil analisis tanah sebelum perlakuan

\begin{tabular}{ll}
\hline \multicolumn{1}{c}{ Sifat Tanah } & \multicolumn{1}{c}{ Nilai } \\
\hline C - Organik & $0,73 \%$ \\
Kapasitas Tukar Kation & $21,93 \mathrm{cmol} / \mathrm{kg}$ \\
Kejenuhan Basa & $22,33 \%$ \\
$\bullet \quad \mathrm{Ca}$ & $\bullet 4,44 \mathrm{cmol} / \mathrm{kg}$ \\
$\bullet \mathrm{Mg}$ & $\bullet 1,94 \mathrm{cmol} / \mathrm{kg}$ \\
$\bullet \mathrm{K}$ & $\bullet 0,38 \mathrm{cmol} / \mathrm{kg}$ \\
$\bullet \quad \mathrm{Na}$ & $\bullet 0,38 \mathrm{cmol} / \mathrm{kg}$ \\
P tersedia & $15,21 \mathrm{ppm}$ \\
Alumuniumdapat & $1,17 \mathrm{cmol} / \mathrm{kg}$ \\
dipertukarkan & \\
pH & 5,04 \\
Tekstur & Liat \\
\hline
\end{tabular}

Berdasarkan kriteria sifat kimia tanah Balittanah (1983), persentase C-Organik tanah tergolong sangat rendah, $\mathrm{pH}$ tanah yang tergolong masam, adapun kandungan Ca tanah tergolong rendah sedangkan $\mathrm{Mg}, \mathrm{K}$, dan $\mathrm{Na}$ tergolong sedang. Hal ini sesuai dengan pendapat Sipayung et al (2014) bahwa tanah ultisol memiliki unsur hara yang rendah, $\mathrm{pH}$ rendah, dan kandungan organik yang rendah. Sifat kimia lainnya, yaitu KTK tanah tergolong sedang dan kejenuhan basa tergolong rendah. Hal ini disebabkan karena kandunahgan unsur hara pada tanah Ultisol rendah sehingga kejenuhan basa rendah pula. P-tersedia dianalisis dengan metode bray, kandungan $\mathrm{P}$ tersedia pada tanah tergolong rendah sedangkan Al-dd tanah tergolong tinggi. Hal ini sesuai dengan pendapat Syahputra et al (2015) bahwa kekurangan fosfat pada tanah Ultisol dapat disebabkan oleh kandungan fosfat dari bahan induk tanah yang sudah pasti rendah, atau kandungan fosfat sebetulnya tinggi tetapi tidak tersedia untuk tanaman karena di serap oleh unsur lain seperti Al dan
Fe. Adapun sifat fisik tanah yang dianalisis adalah tekstur, jenis tekstur tanah termasuk liat.

\section{Tinggi Tanaman}

Rata-rata tinggi tanaman jagung selama umur 56 HST ditunjukkan pada Gambar 2 berikut.

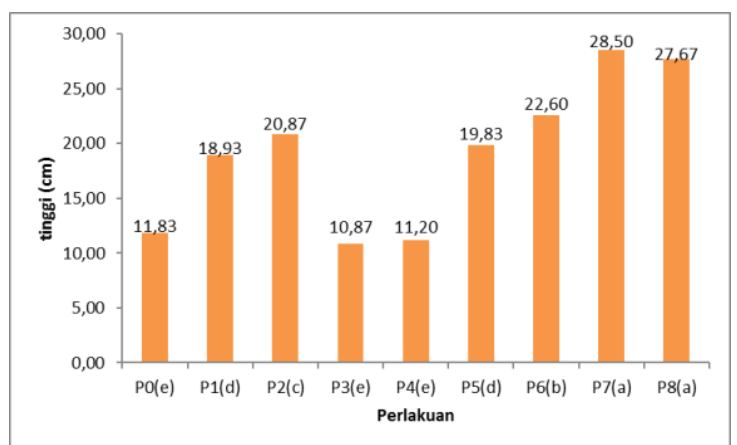

Gambar 1. Grafik rata-rata tinggi tanaman pada setiap perlakuan (perlakuan yang diikuti oleh huruf-huruf yang sama (a,b,c,d,e) berarti tidak berbeda nyata pada uji taraf DMRT 5\%).

Analisis sidik ragam menunjukkan bahwa perlakuan P7 memberikan pengaruh sangat nyata terhadap tinggi tanaman. Gambar 1 menunjukkan bahwa perlakuan P7 menunjukkan hasil tanaman tertinggi, yaitu $28,50 \mathrm{~cm}$ dan P3 menunjukkan hasil tanaman terendah yaitu $10,87 \mathrm{~cm}$. Berdasarkan uji lanjutan DMRT pada taraf 5\% memberikan hasil bahwa perlakuan P7 berbeda nyata dengan P0, P1, P2, P3, P4, P5, dan P6 dan tidak berbeda nyata dengan $\mathrm{P} 8$.

\section{Jumlah Daun}

Analisis sidik ragam menunjukkan bahwa perlakuan P8 memberikan pengaruh sangat nyata terhadap jumlah daun. Gambar 2 menunjukkan bahwa perlakuan P8 menunjukkan hasil nilai rata-rata tertinggi yaitu $7,33 \mathrm{~cm}$ dan $\mathrm{P0}$ menunjukkan hasil rata-rata jumlah daun terendah yaitu $3.67 \mathrm{~cm}$. Berdasarkan uji lanjutan DMRT pada taraf 5\% memberikan hasil bahwa perlakuan P8 berbeda nyata dengan semua perlakuan. 


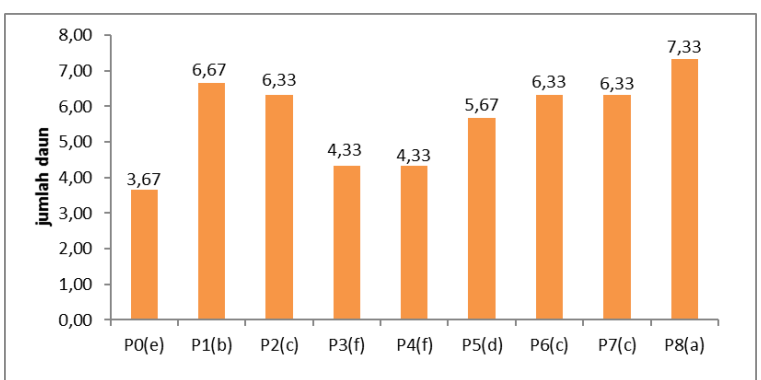

Gambar 2. Grafik rata-rata jumlah daun pada setiap perlakuan (perlakuan yang diikuti oleh huruf-huruf yang sama (a,b,c,d,e,f) berarti tidak berbeda nyata pada uji taraf DMRT 5\%).

\section{Berat Basah Tanaman}

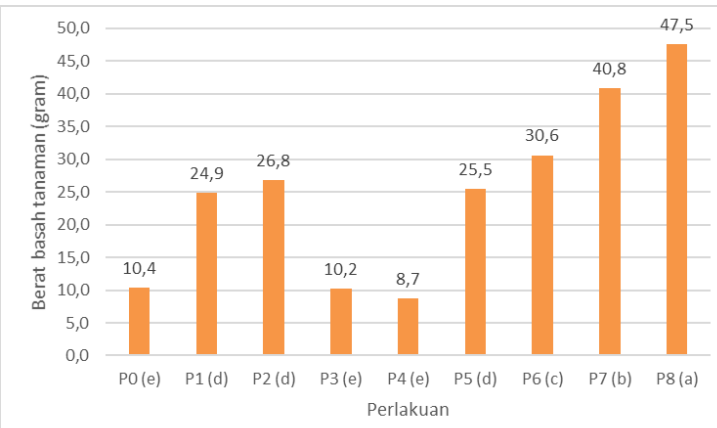

Gambar 3. Grafik rata-rata berat basah tanaman pada setiap perlakuan (perlakuan yang diikuti oleh huruf-huruf yang sama (a,b,c,d) berarti tidak berbeda nyata pada uji taraf DMRT 5\%).

Analisis sidik ragam menunjukkan bahwa perlakuan P8 memberikan pengaruh nyata terhadap berat basah tanaman. Gambar 4menunjukkan bahwa perlakuan P8 menunjukkan hasil berat basah tanaman nilai rata-rata tertinggi yaitu 47,5 gdan $\mathrm{P} 4$ menunjukkan hasil rata-rata berat basah tanaman terendah yaitu $8,7 \mathrm{~g}$. Berdasarkan uji lanjutan DMRT pada taraf 5\% memberikan hasil bahwa perlakuan P8berbeda nyata dengan P0, P1, P2, P3, P4, P5, P6 dan P7.

\section{Berat Kering Tanaman}

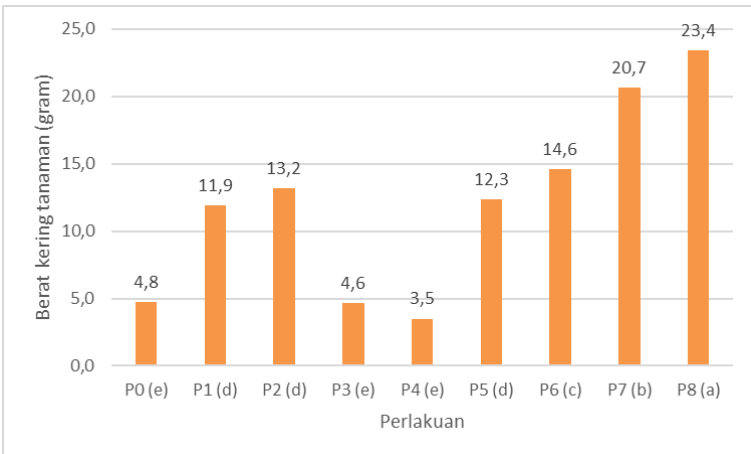

Gambar 4. Grafik rata-rata berat kering tanaman pada setiap perlakuan (perlakuan yang diikuti oleh huruf-huruf yang sama (a,b,c,d) berarti tidak berbeda nyata pada uji taraf DMRT 5\%).

Analisis sidik ragam menunjukkan bahwa perlakuan memberikan pengaruh nyata terhadap berat kering tanaman.Gambar 4 menunjukkan bahwa perlakuan P8 menunjukkan hasil berat kering tanaman nilai rata-rata tertinggi yaitu 23,4 gdan $\mathrm{P} 4$ menunjukkan hasil rata-rata berat kering tanaman terendah yaitu 3,5 g. Berdasarkan uji lanjutan DMRT pada taraf 5\% memberikan hasil bahwa perlakuan P8 berbeda nyata dengan P0, P1, P2, P3, P4, P5, P6 dan P7.

\section{Berat Basah Akar}

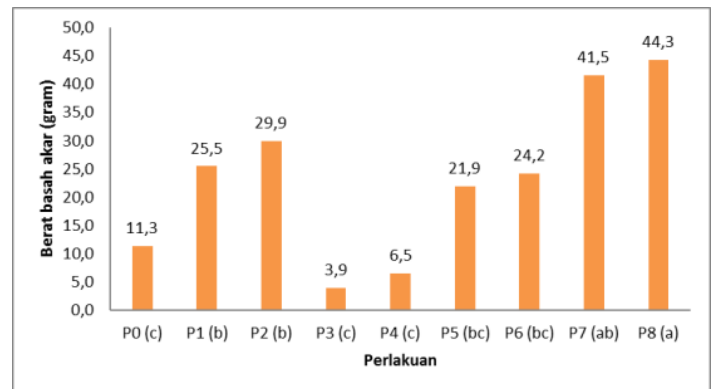

Gambar 5. Grafik rata-rata berat basah tanaman pada setiap perlakuan (perlakuan yang diikuti oleh huruf-huruf yang sama $(a, b, c)$ berarti tidak berbeda nyata pada uji taraf DMRT 5\%). 
Analisis sidik ragam menunjukkan bahwa seluruh perlakuanmemberikan pengaruh nyata terhadap berat basah akar. Gambar 5 menunjukkan bahwa perlakuan P8 menunjukkan hasil berat basah akar nilai rata-rata tertinggi yaitu 44,3 g dan P3 menunjukkan hasil rata-rata berat basah akar terendah yaitu 3,9 g. Berdasarkan uji lanjutan DMRTpada taraf 5\% memberikan hasil bahwa perlakuan P8 berbeda nyata dengan P0, P1, P2, P3, P4, P5, dan P6, namun masih sama dengan perlakuan $\mathrm{P} 7$.

\section{Berat Kering Akar}

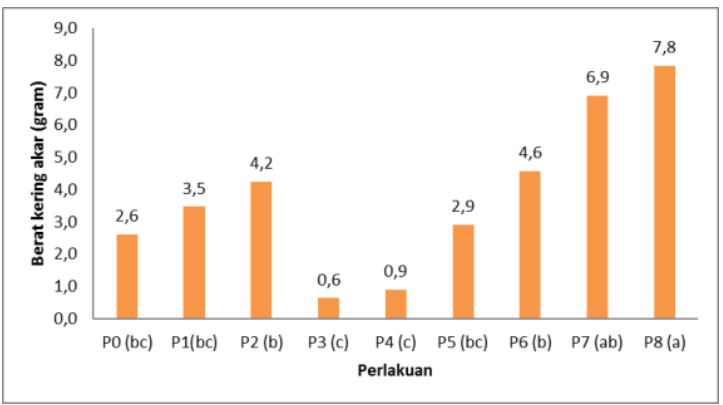

Gambar 6. Grafik rata-rata berat kering tanaman pada setiap perlakuan (perlakuan yang diikuti oleh huruf-huruf yang sama $(a, b, c)$ berarti tidak berbeda nyata pada uji taraf DMRT 5\%).

Analisis sidik ragam menunjukkan bahwa seluruh perlakuan memberikan pengaruh nyata terhadap berat kering akar.Gambar 6 menunjukkan bahwa perlakuan P8 menunjukkan hasil berat kering akar nilai rata-rata tertinggi yaitu $7,8 \mathrm{~g}$ dan P3 menunjukkan hasil rata-rata berat kering terendah yaitu 0,6 g. Berdasarkan uji lanjutan DMRTpada taraf 5\% memberikan hasil bahwa perlakuan P8 berbeda nyata dengan P0, P1, P2, P3, P4, P5, dan P6, tetapi masih memiliki pengaruh yang sama dengan perlakuan P7.

\section{Kemasaman Tanah (pH)}

Analisis sidik ragam menunjukkan bahwa perlakuan P6 memberikan pengaruh sangat nyata terhadap keasaman tanah. Gambar 7 menunjukkan bahwa perlakuan P6 menunjukkan hasil keasaman tanah $(\mathrm{pH})$ nilai rata-rata tertinggi yaitu 6,45 dan $\mathrm{P} 0$ menunjukkan hasil rata-rata kemasaman tanah terendah yaitu 5,04. Berdasarkan uji lanjutan DMRT pada taraf 5\% memberikan hasil bahwa perlakuan P6 berbeda nyata dengan semua perlakuan.

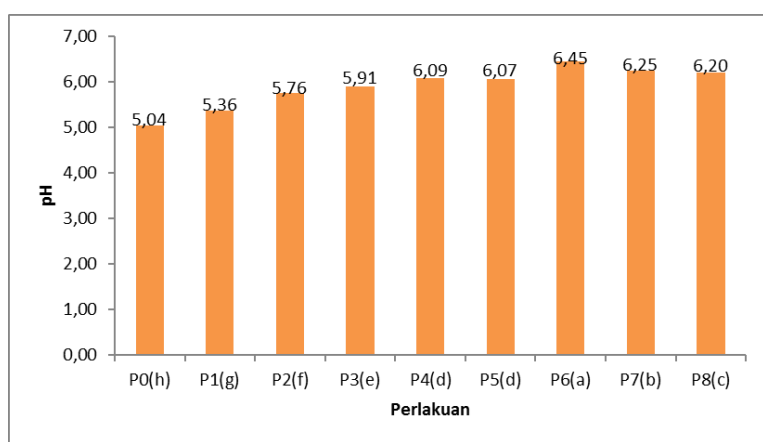

Gambar 7. Grafik rata-rata $\mathrm{pH}$ pada setiap perlakuan (perlakuan yang diikuti oleh huruf-huruf yang sama (a,b,c,d,e,f) berarti tidak berbeda nyata pada uji taraf DMRT 5\%).

\section{Aluminium Dapat Dipertukarkan (Al-dd)}

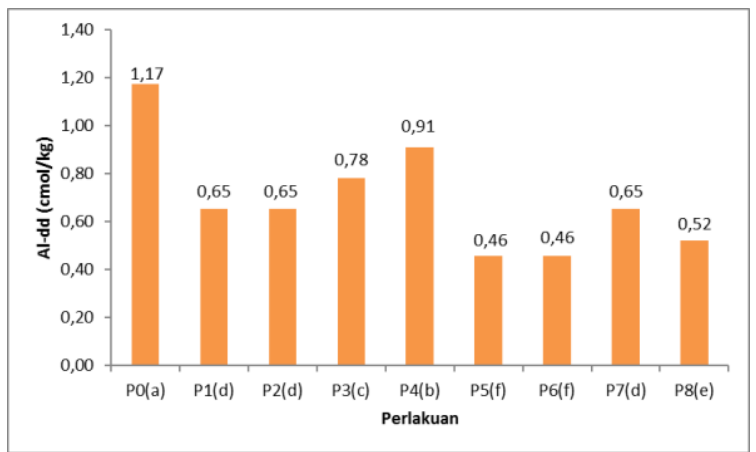

Gambar 8. Grafik rata-rata Al-dd pada setiap perlakuan (perlakuan yang diikuti oleh huruf-huruf yang sama (a,b,c,d,e,f) berarti tidak berbeda nyata pada uji taraf DMRT 5\%).

Analisis sidik ragam menunjukkan bahwa perlakuan memberikan pengaruh sangat nyata terhadap keasaman tanah.Gambar 8 menunjukkan bahwa perlakuan P0 menunjukkan hasil Al-dd nilai rata-rata tertinggi yaitu 1,17dan P5 dan P6 menunjukkan hasil rata-rata Al-dd terendah yaitu 0,46. Berdasarkan uji lanjutan DMRT pada taraf $5 \%$ memberikan hasil bahwa 
perlakuanP5 dan P6 berbeda nyata dengan semua perlakuan.

\section{Kejenuhan Basa}

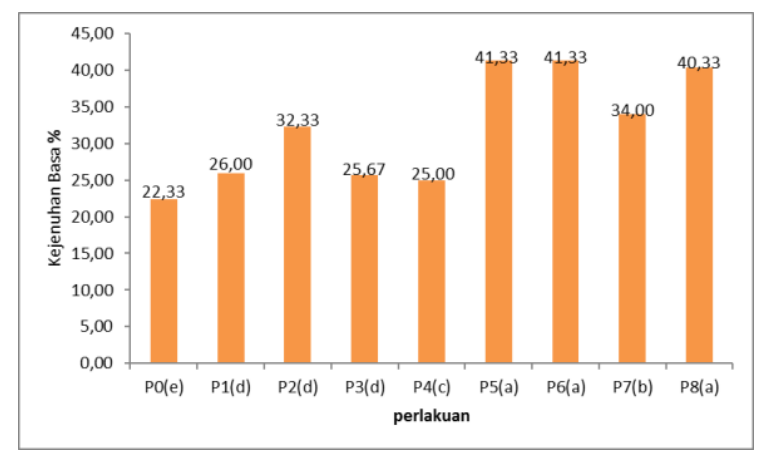

Gambar 9. Grafik rata-rata kejenuhan basa pada setiap perlakuan (perlakuan yang diikuti oleh huruf-huruf yang sama (a,b,c,d,e) berarti tidak berbeda nyata pada uji taraf DMRT 5\%).

Analisis sidik ragam menunjukkan bahwa perlakuan memberikan pengaruh sangat nyata terhadap keasaman tanah. Gambar 9 menunjukkan bahwa perlakuan P5 dan P6 menunjukkan hasil kejenuhan basa nilai rata-rata tertinggi yaitu 41,33dan P0 menunjukkan hasil rata-rata kejenuhan basa terendah yaitu 22,33. Berdasarkan uji lanjutan DMRT pada taraf 5\% memberikan hasil bahwa perlakuan P5 dan P6 berbeda nyata dengan perlakuan $\mathrm{P} 0, \mathrm{P} 1, \mathrm{P} 2, \mathrm{P} 3, \mathrm{P} 4, \mathrm{P} 7$ dan tidak berbeda nyata dengan perlakuan $\mathrm{P} 8$.

\section{Fosfor (P) Tersedia}

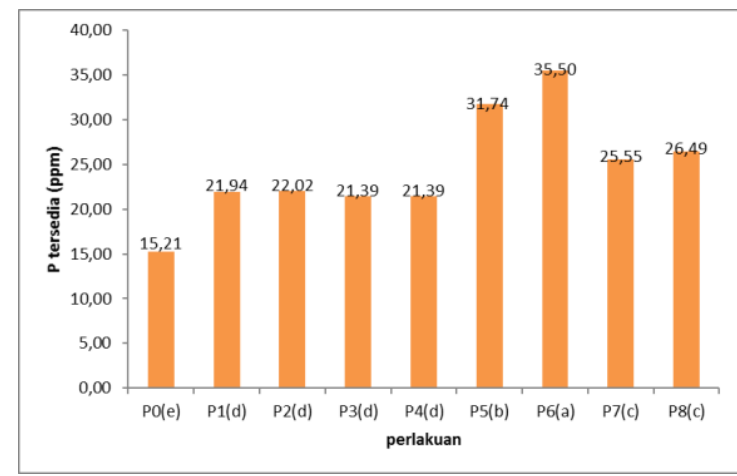

Gambar. 10. Grafik rata-rata P-tersedia pada setiap perlakuan (perlakuan yang diikuti oleh huruf-huruf yang sama $(a, b, c, d, e)$ berarti tidak berbeda nyata pada uji taraf DMRT 5\%).
Analisis sidik ragam menunjukkan bahwa perlakuan memberikan pengaruh sangat nyata terhadap keasaman tanah.Gambar 10 menunjukkan bahwa perlakuan P6 menunjukkan hasil P-tersedia nilai rata-rata tertinggi yaitu 35,50 dan $\mathrm{P} 0$ menunjukkan hasil rata-rata P-tersedia terendah yaitu 15,21. Berdasarkan uji lanjutan DMRT pada taraf 5\% memberikan hasil bahwa perlakuan P6 berbeda nyata dengan semua perlakuan.

\section{Kapasitas Tukar Kation (KTK)}

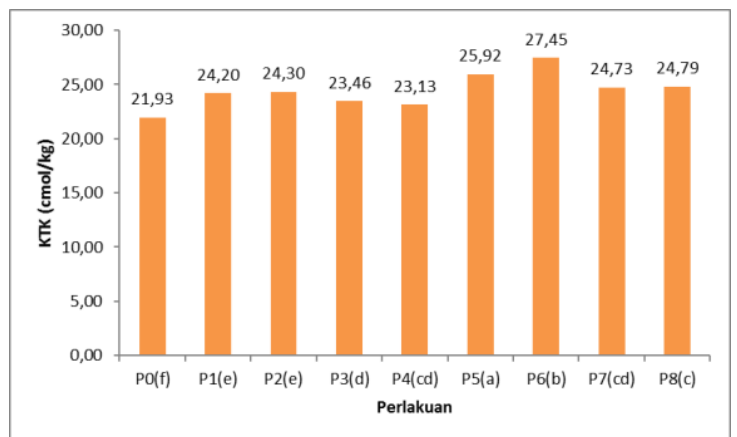

Gambar 11. Grafik rata-rata KTK pada setiap perlakuan (perlakuan yang diikuti oleh huruf-huruf yang sama (a,b,c,d,e,f) berarti tidak berbeda nyata pada uji taraf DMRT 5\%).

Analisis sidik ragam menunjukkan bahwa perlakuan memberikan pengaruh sangat nyata terhadap keasaman tanah. Gambar 11 menunjukkan bahwa perlakuan P6 menunjukkan hasil KTK nilai rata-rata tertinggi yaitu 27,45 dan P0 menunjukkan hasil rata-rata KTK terendah yaitu 21,93. Berdasarkan uji lanjutan DMRT pada taraf 5\% memberikan hasil bahwa perlakuan P6 berbeda nyata dengan semua perlakuan.

\section{C-Organik}

Analisis sidik ragam menunjukkan bahwa perlakuan memberikanpengaruh sangat nyata terhadap C-organik. Gambar 12 menunjukkan bahwa perlakuan P6 menunjukkan hasil C-organik nilai rata-rata tertinggi yaitu 1,07 dan P0 menunjukkan hasil rata-rata $\mathrm{C}$-organik terendah yaitu 0,73 . Berdasarkan uji lanjutan DMRT pada taraf 
5\% memberikan hasil bahwa perlakuan P6 berbeda nyata dengan semua perlakuan.

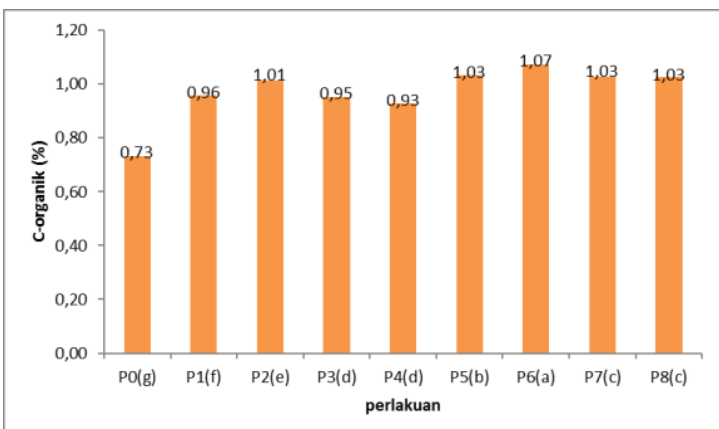

Gambar 12. Grafik rata-rata C-organik pada setiap perlakuan (perlakuan yang diikuti oleh huruf-huruf yang sama (a,b,c,d,e,f,g) berarti tidak berbeda nyata pada uji taraf DMRT 5\%).

\section{Pembahasan}

\section{Pengaruh Perlakuan terhadap Pertumbuhan Tanaman Jagung}

Pengaruh perlakuan terhadap tanaman jagung ditunjukkan berdasarkan tinggi tanaman, jumlah daun, berat basah dan berat kering. Berdasarkan tinggi tanaman, perlakuan P7 menunjukkan hasil terbaik. Perlakuan P7 merupakan perlakuan pupuk kompos pelet 5 ton/ha. Hasil tersebut dipengaruhi oleh perlakuan pupuk organik yang diaplikasikan ke tanaman jagung. Pemberian pupuk sangat mempengaruhi pertumbuhan tanaman jagung pada fase vegetatif. Unsur hara $\mathrm{N}, \mathrm{P}$ dan $\mathrm{K}$ yang tersedia dalam jumlah yang optimal dan seimbang akan mampu memberikan keseimbangan hara makro bagi tanaman. Menurut Hidayah et al (2016), pupuk kandang ayam meningkatkan efektivitas pemupukan $\mathrm{N}$, di mana unsur $\mathrm{N}$ yang lepas dari pupuk diikat oleh bahan organik, sehingga tidak mudah tercuci oleh hujan. Hasil penelitian Hidayah et al (2016), menunjukkan bahwa pemberian 10 ton/ha pupuk kandang ayam berpengaruh nyata terhadap pertumbuhan tanaman pada variabel tinggi jagung.Seperti yang dikutip pula oleh Harjadi (2002) dalam Syahriani (2014), yang menyatakan bahwa unsur hara yang tersedia dalam jumlah yang cukup untuk pertumbuhan tanaman menyebabkan proses pemanjangan sel berlangsung cepat sehingga mengakibatkan pertumbuhan batang, daun, akar pada tanaman berlangsung cepat. Berdasarkan uji lanjutan, perlakuan P8 memiliki pengaruh yang sama dengan P7. Hal ini disebabkan karena kedua perlakuan merupakan perlakuan pupuk kompos pelet meskipun pada dosis yang berbeda. Hal ini membuktikan bahwa pada dosis 5-10 ton/ha sudah bisa memberikan pengaruh yang baik terhadap pertumbuhan tinggi tanaman jagung.

Berdasarkan parameter jumlah daun, perlakuan P8 memberikan hasil terbaik. Perlakuan P8 merupakan pupuk kompos pelet 10 ton/ha. Penggunaan pupuk kompos dalam bentuk pelet memberikan pengaruh yang lebih efektif terhadap pertumbuhan tanaman sebab pelepasan unsur hara dilakukan secara slow release akibatnya unsur hara akan relatif lebih tersedia untuk tanaman jagung. Menurut Jusuf (2008), salah satu bahan organik yang bisa dijadikan sebagai bahan pupuk organik pelet adalah daun glirisidia. Glirisidia termasuk jenis leguminoceae sehingga kandungan nitrogen di daun cukup tinggi. Hasil penelitian Wong dan Paulus (1993) menunjukkan bahwa unsur hara yang terkandung dalam bahan kering glirisidia adalah $2,72 \% \mathrm{~N} ; 0,182 \%$ $\mathrm{P}_{2} \mathrm{O}_{5} ; 1,79 \% \quad \mathrm{~K}_{2} \mathrm{O} ; 1,46 \% \quad \mathrm{CaO} ; \quad 0,33 \%$ $\mathrm{MgO}$.Fungsi Nitrogen bagi tanaman cukup kompleks, namun yang paling utama adalah memperbaiki struktur pertumbuhan vegetatif tanaman dengan membentuk enzim-enzim yang berperan dalam mempercepat pertumbuhan tanaman, membentuk daun dan produksi bahan kering, merangsang pertumbuhan dahan, serta memperbanyak jumlah anakan pada tanaman. Berdasarkan uji lanjutan, perlakuan P8 berbeda nyata dengan semua perlakuan. Hal ini berarti perlakuan P8 memberikan pengaruh yang lebih efektif pada parameter jumlah daun.

Ditinjau dari parameter pertumbuhan tanaman lainnya, yaitu berat basah/kering 
tanaman dan akar. Berat basah menunjukkan massa tanaman/akar dan jumlah air yang diserap oleh tanaman sedangkan berat kering menujukkan massa tanaman/akar sesungguhnya sebagai hasil dari proses fotosintesis. Perlakuan yang memberikan pengaruh terbaik terhadap berat basah dan berat kering akar maupun tanaman adalah perlakuan P8 yang merupakan perlakuan pupuk kompos pelet10 ton/ha. Perlakuan ini menunjukkan hasil terbaik karena penggunaan kombinasi daun gamal, jerami, dan pupuk kandang. Menurut Jusuf dan Sanaba (2007), daun gamal dapat dijadikan sebagai pupuk organik sebab memiliki kandungan nitrogen yang tinggi sehingga sangat cocok jika diaplikasikan pada tanaman yang menghasilkan bagian vegetatif sebagai bagian tanaman yang dipanen. Ketika diaplikasikan pada tanaman jagung maka pertumbuhan vegetatifnya akan membaik, begitu pula akan memengaruhi berat total tanaman.

Selain daun gamal, pupuk kompos pelet juga mengandung pupuk kandang. Pupuk kandang dapat memperbaiki struktur dan tekstur tanah, menaikkan daya serap tanah terhadap air, menaikkan kondisi kehidupan di dalam tanah dan sebagai sumber zat makanan bagi tanaman. Menurut Wiryanta dan Bernardinus (2002), kadar unsur hara yang terkandung dalam pupuk kandang ayam, yaitu $\mathrm{N} 3,21 \%, \mathrm{P}_{2} \mathrm{O}_{5} 3,21 \%$, $\mathrm{K}_{2} \mathrm{O} 1,57 \%, \mathrm{Ca} 1,57 \%, \mathrm{Mg} 1,44 \%, \mathrm{Mn} 250$ ppm dan Zn 315 ppm. Penggunaan jerami padi pun memengaruhi hal ini sebab jerami memiliki kandungan unsur hara yang dapat mendukung pertumbuhan vegetatif tanaman. Jerami padi juga merupakan bahan organik yang dapat memperbaiki sifat biologitanah sehingga tercipta lingkungan yang lebih baik bagi perakaran tanaman. Selainitu bahan organik jerami padi dapat mensuplai unsur hara terutama N, P dan K. Semakin tinggi dosis bahan organik maka semakin tinggi konsentrasi N, P dan $\mathrm{K}$ didalam tanaman. Semua unsur-unsur tersebut memegang peran yang sangat pentingdalam metabolisme tanaman (Pangaribuan dan Pujisiswanto, 2008).

\section{Pengaruh Perlakuan terhadap Tanah}

Berdasarkan hasil analisis yang dilakukan di laboratorium, maka diperoleh kandungan unsur kimia tanah berbeda pada masing perlakuan.Terdapat perbedaan yangsignifikanantara perlakuan kontrol (P0) dan perlakuan lainnya, secara uji lanjutan perlakuan P0 berbeda nyata dengan semua perlakuan pada semua parameter tanah, hal ini menandakan bahwa adanya efektivitas perlakuan terhadap sifat kimia tanah.

Ditinjau dari nilai kemasaman tanah, perlakuan terbaik terdapat pada tanah dengan perlakuan P6 (pupuk kandang 10 ton/ha + pupuk kompos 5 ton/ha) yang menunjukkan hasil $\mathrm{pH}$ tertinggi, yaitu 6,45. Berdasarkan criteria penilaian sifat kimia tanah oleh staf pusat penelitian tanah (1983), nilai ini masih tergolong agak masam (Hardjowigeno, 2003). Terjadi peningkatan $\mathrm{pH}$ tanah sebelum dan sesudah pemupukan dari tergolong masam $(5,04)$ hingga menjadi agak masam, hal ini disebabkan karena penggunaan pupuk organic dapat menambah jumlah senyawa-senyawa organic dalam tanah yang dapat mengikat $\mathrm{H}$ dan $\mathrm{Al}$ sebagai penyebab kemasaman tanah. Menurut Afandi et al (2015), Pengaruh pemberian bahan organicdapat meningkatkan $\mathrm{pH}$ tanah meskipunpeningkatannya masih dalam kategori masam.Tingkatkemasaman tanah akibat daripemberian bahan organik bergantung padatingkat kematangan dari bahan organik yangdiberikan, batas kadaluarsa dari bahan organikdan jenis tanahnya. Jika penambahan bahanorganik yang masih belum matang akanmenyebabkan lambatnya proses peningkatanpH tanah dikarenakan bahan organik masihbelum terdekomposisi dengan baik dan masihmelepaskan asam-asam organik.

Sejalan dengan peningkatan $\mathrm{pH}$ maka kandungan Al-dd pada tanah pun semakin rendah pula. Perlakuan P6 menunjukkan kandungan Al-dd terendah $(0,46 \mathrm{cmol} / \mathrm{kg})$ yang sejalan dengan hasil $\mathrm{pH}$ tanah pada perlakuan P6 menunjukkan pula nilai tertinggi. Sesuai dengan pendapat Kidd (2001) dalam Krsticet al (2012) bahwa 
seiring dengan menurunnya $\mathrm{pH}$, kelarutan dan daya toxic aluminium (Al) meningkat dalam tanah sehingga untuk meningkatkankan $\mathrm{pH}$ maka perlu mengendalikan kandungan $\mathrm{Al}$ dalam tanah. Secara uji lanjutan, perlakuan P6 memberikan pengaruh yang berbeda nyata dengan semua perlakuan, kecuali perlakuan P5. Hal ini disebabkan oleh kedua perlakuan ini merupakan kombinasi dua jenis pupuk organik, yang membedakan hanya dosis tiap jenis pupuk organic sehingga memungkinkan memberikan efek yang sama.

Berdasarkan hasil yang didapatkan dari sifat kimia tanah lainnya, yaitu kejenuhan basah. Tingkat kejenuhan basa secara keseluruhan mengalami peningkatan dari sebelum hingga setelah perlakuan yang tergolong rendah hingga sedang. Perlakuan P5 dan P6 menunjukkan nilai kejenuhan basa tertinggi, yaitu $41,33 \%$. Persentase nilai kejenuhan basa ini tergolong sedang (staf pusat penelitian tanah, 1983 dalam Hardjowigeno, 2003). Peningkatan tersebut dapat terjadi sebab penggunaan kombinasi pupuk kompos dan pupuk kandang yang dapat meningkatan ketersediaan kationkation basa sehingga jumlah kation basa meningkat. Sama halnya dengan pengaruh perlakuan terhadap Al-dd, perlakuan P5 dan P6 menunjukkan pengaruh yang sama, hal ini berarti penggunaan kombinasi pupuk kandang dan pupuk lebih efektif dalam mengendalikankan dungan $\mathrm{Al}$ dan dapat meningkatkan jumlah kation-kation basa dalam tanah.

Sesuai dengan hasil yang ditunjukkan pada kejenuhan basa, Kapasitas Tukar Kation (KTK) pada tanah setelah keseluruhan perlakuan mengalami peningkatan dari sedang menjadi tinggi. Nilai KTK tertinggi ditunjukkan pada perlakuan P6 $(27,45 \mathrm{cmol} / \mathrm{kg})$, telah diuji DMRT taraf $5 \%$ memberi pengaruh yang berbeda nyata dengan semua perlakuan. Hal ini disebabkan adanya korelasi positif antara kejenuhan basa dan KTK. Menurut Nasrul et al (2002), keadaan kejenuhan basa yang rendah dapat mengakibatkan ketersediaan unsur hara dan KTK menjadi rendah.
Peningkatan kejenuhan basa diakibatkan karena pupuk organik memungkinkan penambahan unsur hara makro. Menurut Benny (2010)dalam Prasetyo (2014), pupuk organik memiliki fungsi kimia yang penting seperti penyediaan hara makro (nitrogen, fosfor, kalium, kalsium, magnesium, dan sulfur) dan hara mikro seperti zink, tembaga, kobalt, barium, mangan, dan besi meskipun dalam jumlah yang kecil, meningkatkan kapasitas tukar kation tanah, dan membentuk senyawa kompleks dengan ion logam yang meracuni tanaman seperti aluminium, besi, dan mangan.

Terdapat pula peningkatan kandungan hara $\mathrm{P}$ setelah diberikan perlakuan, secara keseluruhan perlakuan menunjukkanadanya peningkatan ketersediaanP ditandai dengan adanya pengaruh yang berbeda nyata antara $\mathrm{P} 0$ dan semua perlakuan. Peningkatan $\mathrm{P}$ tersedia tertinggi ditunjukkan pada perlakuan P6 yaitu 35,5 ppm. Berdasarkan kriteria penilaian sifat kimia tanah oleh staf pusat penelitian tanah (1993), nilai $\mathrm{P}$ tersedia tergolong sedang. Kandungan unsur hara $\mathrm{P}$ pada tanah sebelum dan sesudah perlakuan mengalami peningkatan kandungan dari rendah ke sedang. Hal ini disebabkan karena kombinasipupuk organik kandang dan kompos dapat menambah jumlah senyawa organik dalam tanah yang dapat mengikat $\mathrm{Al}$ bebas tanah dengan gugus fungsionalnya sehingga $\mathrm{P}$ dapat meningkatkan $\mathrm{pH}$ tanah akibatnya $\mathrm{P}$ dapat lebih tersedia. Kebanyakan $\mathrm{P}$ diserap dalam bentuk ion anorganik orthofosfat: $\mathrm{HPO}_{4}{ }^{2-}$ atau $\mathrm{H}_{2} \mathrm{PO}_{4}{ }^{-}$. Jumlahnya tergantung $\mathrm{pH}$ larutan, pada $\mathrm{pH}$ 7,2 jumlahnya setara.

Pemberian perlakuan pupuk organik akan meningkatkan kandungan C-organik dalam tanah.Halini terjadi karena pupuk organik merupakan sumber karbon untuk tanah. Perlakuan yang paling efektif meningkatkan kandungan C-organik adalah perlakuan P6 (1,07\%). Penggunaan kombinasi pupuk kandang dan pupuk kompos dapat lebih cepat meningkatkan kandungan C-organik tanah meskipun peningkatan yang terjadi masih tergolong 
rendah (stafpusatpenelitiantanah, 1993 dalam Hardjowigeno 2003). Sesuai dengan pendapat Zulkarnain et al (2013), bahwa aplikasi kompos dan pupuk kandang dapat meningkatkan C-organik tanah. Semakin banyak pupuk organik yang ditambahkan ke dalam tanah, semakin besar peningkatan kandungan C-organik dalam tanah.

\section{KESIMPULAN}

Berdasarkan hasil dan pembahasan dapat disimpulkan sebagai berikut:

1. Perlakuan pupuk kandang 10 ton/ha ditambah pupuk kompos 5 ton/ha merupakan perlakuan paling berpengaruhnyata untuk menurunkan kandungan Al-dd pada tanah ultisol, dan meningkatkan $\mathrm{P}$ tersedia, $\mathrm{pH}$, kejenuhan basa, kapasitas tukar kation, dan Corganik pada tanah Ultisol.

2. Perlakuan pupuk pelet 10 ton/ha merupakan perlakuan yang paling berpengaruh nyata terhadap pertumbuhan tanaman jagung.

\section{DAFTAR PUSTAKA}

Afand, Fahriansyah Nur, Bambang Siswanto, Yulia Nuraini. 2015. Pengaruh Pemberian Berbagai Jenis Bahan Organik terhadap Sifat Kimia Tanah pada Pertumbuhan dan Produksi Tanaman Ubi Jalar di Entisol Ngrangkah Pawon, Kediri. Jurnal Tanah dan Sumberdaya Lahan Vol. 2 No. 2: 237-244.

Anwar S, Sudadi U. 2013. Kimia Tanah. Bogor (ID): IPB Press.

Badan Litbang Pertanian.2005. Warta Penelitian dan Pengembangan Pertanian, Volume 27 nomor 6.PusatPenyebaran Informasi Pertanian. Badan Litbang Pertanian. Deptan

Bonifas, Kimberly, Daniel T.W., Kenneth G. Cassman, dan John L.L. 2005.
Nitrogen supply affects root:shoot ratio in corn and velvetleaf (Abutilon theophrasti). Weed Science, 53:670675.

Hardjowigeno, S. 2003. Klasifikasi Tanah dan Pedogenesis. Jakarta (ID): Akademika Pressindo.

Harris, Richard W. 1992. Root-Shoot Ratios. Journal of Arboriculture 18(1): 39 - 42.

Hartatik, W., Suriadikarta, D.A., Prihati, T. 2002. Teknologi Pengelolaan Bahan Organik Tanah. Bogor (ID): Pusat Penelitian dan Pengembangan Tanah dan Agroklimat.

Hidayah, Umur, Palupi Puspitorini, Agung Setya. 2016. Pengaruh Pemberian Pupuk Urea dan Pupuk Kandang Ayam terhadap Pertumbuhan dan Hasil Tanaman Jagung Manis (Zea mays Saccharata Sturt. L) Varietas Gendis. Jurnal Viabel Pertanian Vol. 10 No. 1.

Jusuf L, AM Mulyati dan AH Sanaba. 2007. Pengaruh Dosis Pupuk Organik Padat Daun Gamal Terhadap Tanaman Sawi. Jurnal Agrisistem. 3(2): 80-89.

Jusuf L. 2008. Pengaruh Lama Pengomposan Daun Gamal Terhadap Pertumbuhan Tanaman Sawi. Jurnal Agrisistem. 4(1): 44-52.

Krstic, Dragana, Ivica Djalovic, Dragoslav Nikezic, dan Dragana Bjelic. 2012. Aluminium in Acid Soils: Chemistry, Toxicity and Impact on Maize Plants (Food Production - Approaches, Challenges and Tasks). ISBN 978-953307-887-8. InTech, Croatia.

Martajaya, M. 2010. Metode Budidaya Organik Tanaman Jagung Manis di Telagamas, Malang. Jurnal Pembangunan dan Alam Lestari. 1(1): 1-4.

Mayadewi, A. 2007. Pengaruh Jenis Pupuk Kandang dan Jarak Tanam terhadap Pertumbuhan Gulma dan Hasil 
Tanaman Jagung. Agritrop. 26(4): 153-159.

Murbandono, H. S. 2000. Pembuatan Kompos. Penebar Swadaya. Jakarta

Murselindo, A.A. 2014. Pengaruh Pupuk NPK Pelet dari Kotoran Ayam terhadap Pertumbuhan dan Hasil Tanaman Kedelai (Glycine max 1.) di Tanah Regosol. Planta Tropika Journal of Agro Science. 2(2): 75 - 80.

Nasrul, B., A. Hamzah. Dan E. Anom. 2002. Klasifikasi Tanah dan Evaluasi Kesesuaian Lahan Kebun Percobaan Fakultas Pertanian Universitas Riau. Jurnal sagu Vol (2) (2002): 16-26. Pekanbaru.

Pangaribuan, D., dan H. Pujisiswanto. 2008. Pemanfaatan Kompos Jerami UntukMeningkatkan Produksi dan Kualitas Buah Tomat.Prosiding Seminar Nasional Sains dan Teknologi-II. Universitas Lampung 7(1). Hlm 6-8.

Prasetyo, B. H., dan Suriadikarta, D. A. 2006. Karakteristik, Potensi, dan Teknologi Pengelolaan Tanah Ultisol Untuk Pengembangan Pertanian Lahan Kering di Indonesia. Jurnal Litbang Pertanian Bogor, 25 (2): 39 - 47.

Prasetyo, Rendy. 2014. Pemanfaatan Berbagai Sumber Pupuk Kandang sebagai Sumber N dalam Budidaya Cabai Merah (Capsicum annum) Tanah Berpasir. Planta Tropia Journal of Agro Science Vol. 2 No. 2.

Rosmankam, A., dan Yuwono, N.W. 2002. Ilmu Kesuburan Tanah. Yogyakarta (ID): Kanisius.

Ruhnayat A. 2006. Respon Dua Klon Harapan Panili Terhadap Pemupukan Organik. Balittro: Laporan Teknis Hasil Penelitian.

Sipayung, Evan Sanjaya, Gantar Sitanggang, M. M. B. Damanik. 2014. Perbaikan Sifat Fisik dan Kimia Tanah Ultisol
Simalingkar B Kecamatan Pancur Batu Dengan Pemberian Pupuk Organik Supernasa dan Rockphosphit serta Pengaruhnya terhadap Produksi Tanaman Jagung (Zea Mays L.). Jurnal online Agroekoteknologi Vol. 2 No.2.

Syahputra, E., Fauzai, Razali. 2015. Karakteristik Sifat Kimia Sub Grup Tanah Ultisol di Beberapa Wilayah Sumatera Utara. Jurnal Agroekoteknologi, 4 (1): 1796 - 1803.

Syahriani. 2014. Perbaikan Kualitas Lahan Kering melalui Pertanian Terpadu Rambutan, Jagung, dan Gamal di Kabupaten Gowa (Skripsi). Universitas Hasanuddin, Makassar.

Winarso, S.2005. Kesuburan Tanah: Dasar Kesehatan dan Kualitas Tanah. Yogyakarta (ID): Gava media.

Wiryanta. W dan Bernardinus.T. 2002. Bertanam Cabai Pada Musim Hujan. Agromedia Pustaka, Jakarta.

Wong TH and AD Paulus. 1993. Evaluation Of Five Supports For Black Pepper. The Pepper Industry Problems and Prospects : 24-34.

Yuliprianto H. 2010. Biologi Tanah dan Strategi Pengelolaannya. Yogyakarta (ID): Graha Ilmu.

Zulkarnain, Maulana, Budi Prasetya, Soemarno. 2013. Pengaruh Kompos, Pupuk Kandang, dan Custom-Bio terhadap Sifat Tanah Pertumbuhan dan Hasil Tebu pada Entisol di Kebun Ngrangkah-Pawon, Kediri. Indonesian Green Technology Journal E-ISSN 2338.1787. 